\begin{tabular}{cc}
\hline UNIVERSITAS AHMAD DAHLAN \\
JURNAL BIOEDUKATIKA \\
2338 h
\end{tabular}

\title{
Implementasi model guided inquiry melalui lesson study untuk meningkatkan penguasaan keterampilan proses sains (KPS) di SMP Muhammadiyah 3 Purwokerto
}

\author{
Listika Yusi Risnani a, 1, ${ }^{*}$, Vian Harsution ${ }^{\text {b, }}{ }^{2}$, Apri Restiana Deri ${ }^{b, 3}$ \\ a Pendidikan Biologi FKIP, Universitas Muhammadiyah Purwokerto, Jalan Raya Dukuhwaluh PO BOX 202, Kembaran Purwokerto \\ 53182, Indonesia \\ b SMP Muhammadiyah 3 Purwokerto, Jalan Dr. Angka No. 79, Purwokerto 53121, Indonesia \\ ${ }^{1}$ listikayusirisnani@ump.ac.id;2 vharsution@gmail.com; ${ }^{3}$ apriresti485@gmail.com \\ *korespondensi penulis
}

\begin{tabular}{ll}
\hline Informasi artikel \\
\hline Sejarah artikel: \\
Diterima & 15 April 2018 \\
Revisi & 1 Agustus 2018 \\
Dipublikasikan & 2 November 2018 \\
\hline
\end{tabular}

\section{Kata kunci:}

Guided inquiry

Keterampilan proses sains Lesson study

\section{ABSTRAK}

Tujuan penelitian adalah mengetahui efektivitas model guided inquiry untuk meningkatkan penguasaan KPS melalui lesson study. Penelitian dilaksanakan sebanyak 6 siklus (plan, do dan see) pada peserta didik kelas VIIIA SMP Muhammadiyah 3 Purwokerto semester gasal tahun ajaran 2016/2017. Teknik pengumpulan data menggunakan wawancara, observasi, tes. Wawancara dilakukan untuk mengumpulkan data tentang kondisi awal peserta didik. Observasi digunakan untuk menggali persentase peserta didik yang melakukan KPS, menghimpun data aspek KPS yang muncul pada setiap siklus dan keterlaksanaan sintaks model guided inquiry. Instrumen tes tertulis digunakan untuk mengukur penguasaan KPS peserta didik. Data dianalisis menggunakan analisis deskriptif kualitatif dan kuantitaif. Hasil penelitian menunjukkan peningkatan kualitas pembelajaran dari siklus 1 hingga siklus 6 dan terjadi peningkatan keterlibatan peserta didik pada aktivitas KPS secara berturut-turut adalah 43\% (kurang), 56\% (cukup), 61\% (cukup), $52 \%$ (cukup), 65\% (cukup), dan $69 \%$ (cukup). Penguasaan KPS peserta didik menunjukkan tingkat penguasaan basic skills dalam kategori baik, process skills dan investigative skills dalam kategori kurang hingga baik. Hasil tes KPS menunjukan hasil yang baik dengan rata-rata nilai sebesar 74,5 dengan standar deviasi 7,9. Simpulan penelitian, implementasi model pembelajaran guided inquity melalui lesson study efektif meningkatkan penguasaan KPS peserta didik kelas VIIIA SMP Muhammadiyah 3 Purwokerto.

Key word:

Guided inquiry

Science process skills

Lesson study

\section{ABSTRACT}

Implementation of guided inquiry model through lesson study to enhance mastery of science process skills (SPS) at SMP Muhammadiyah 3 Purwokerto. The purpose of this research is to know the effectiveness of guided inquiry model to increase SPS through lesson study. The research was conducted 6 cycles (plan, do and see) in class VIIIA students of SMP Muhammadiyah 3 Purwokerto in the academic year of 2016/2017. Technique of collecting data using interview, observation, test. Interviews were conducted to collect data about the initial condition of the learner. Observations were used to probe the percentage of students who did the SPS, collecting the SPS aspect data that appeared on each cycle and the implementation of the guided inquiry syntax. Written test instruments are used to measure students' SPS mastery. Data were analyzed using qualitative and quantitative descriptive analysis. The results of the study showed improvement of learning quality from cycle 1 to cycle 6 and increased participation of students in SPS activity were $43 \%$ (less), 56\% (enough), 61\% (enough), 52\% (enough) 65\% (enough), and 69\% (enough). Mastery of SPS by student shows mastery level to basic skills (good), process skills and investigative skills (less until enough). Mastery of SPS levels with an average score of 74.5 with a standard deviation of 7.9. The conclusion of the research is that the implementation of guided inquiry learning model through lesson study is effective to improves the mastery of Science Process Skills for Students in SMP Muhammadiyah 3 Purwokerto. 


\section{Pendahuluan}

IPA/Sains merupakan cara mencari tahu (inquity) tentang kejadian di alam secara sistematis dengan melibatkan proses pencarian, investigasi dan verifikasi (Badan Standar Nasional Pendidikan, 2006). IPA dipandang sebagai proses (science as process), peserta didik yang belajar IPA melakukan kegiatan mengamati, menyimpulkan dan bereksperimen sehingga inquiry/penyelidikan merupakan basis dari pembelajaran IPA (Harlen, 2001). Keberhasilan belajar IPA bukan hanya sekedar penguasaan fakta, konsep, teori, dan prinsip sains tetapi juga penguasaan proses. Penguasaan keterampilan proses peserta didik lebih penting daripada pengajaran produk sains (Nworgu \& Otum, 2013). Di Indonesia, hal tersebut diperkuat oleh adanya Standar Proses Pendidikan Dasar dan Menengah yang tertuang dalam Permendikbud RI nomor 65 tahun 2016 menyatakan bahwa salah satu sasaran pembelajaran adalah keterampilan yang dielaborasikan pada setiap satuan pendidikan. Keterampilan diperoleh melalui pembelajaran dengan menggunakan pendekatan saintifik yang meliputi mengamati, menanya, mencoba, menalar, mengkomunikasikan sehingga perlu pembelajaran yang menerapkan modus belajar berbasis penelitian (Kemendikbud, 2016). Berdasarkan standar proses tersebut, IPA sebagai salah satu mata pelajaran di Sekolah Menengah Pertama (SMP) berkaitan erat dengan pendekatan saintifik yang melibatkan metode ilmiah (scientific method) dan keterampilan proses sains (KPS). Pembelajaran IPA di SMP idealnya dilaksanakan melalui pembelajaran dengan melatihkan dan mengembangkan KPS kepada peserta didik.

KPS merupakan keterampilan yang dimiliki seseorang untuk melakukan sejumlah proses dalam rangka menerima, memperoleh dan mengembangkan ilmu sains (science knowledge). KPS sebagai proses mental dan perilaku fisik yang digunakan dalam memperoleh, memahami, dan melakukan interpretasi terhadap data yang berupa fakta-fakta atau bukti untuk meningkatkan pengetahuan atau pemahaman (Nworgu \& Otum, 2013). KPS digolongkan menjadi dua yaitu keterampilan dasar/basic skills dan keterampilan terintegrasi/integrated skills (Rezba, Sprague, Matkins, Fiel, \& Mcdonnough, 2007). Pendapat lain menyatakan bahwa KPS dapat dibagi menjadi tiga tingkatan yaitu keterampilan dasar (basic skills), keterampilan mengolah atau memproses (process skills) dan keterampilan melakukan investigasi (investigative skills) (Bryce, T.G.K., McCall, J., MacGregor, J., Robertson, I.J., \& Weston, 1990). Pada penelitian ini menggunakan pembagaian KPS menjadi tiga yaitu keterampilan dasar, keterampilan proses atau mengolah, dan keterampilan melakukan investigasi. Adapun rinciannya tersaji dalam Tabel 1.

Tabel I. Aspek KPS yang dikembangkan pada peserta didik

\begin{tabular}{|c|c|}
\hline $\begin{array}{c}\text { Tingkatan } \\
\text { Keterampilan } \\
\text { Proses Sains } \\
\text { (KPS) }\end{array}$ & $\begin{array}{l}\text { Aspek Keterampilan Proses Sains } \\
\text { (KPS) }\end{array}$ \\
\hline \multirow{5}{*}{$\begin{array}{l}\text { Keterampilan dasar } \\
\text { (basic skills) }\end{array}$} & Keterampilan mengamati \\
\hline & Keterampilan merekam data/ informasi \\
\hline & Keterampilan melakukan pengukuran \\
\hline & $\begin{array}{l}\text { Keterampilan melakukan manipulasi } \\
\text { gerakan }\end{array}$ \\
\hline & $\begin{array}{l}\text { Kemampuan mengimplementasikan } \\
\text { prosedur/ teknik/ penggunaan peralatan }\end{array}$ \\
\hline \multirow{3}{*}{$\begin{array}{l}\text { Keterampilanmeng } \\
\text { olah/ memproses } \\
\text { (process skill) }\end{array}$} & Keterampilan membuat prediksi \\
\hline & Keterampilan membuat inferensi \\
\hline & $\begin{array}{l}\text { Keterampilan memilih/ menyeleksi } \\
\text { prodesur }\end{array}$ \\
\hline \multirow{3}{*}{$\begin{array}{c}\text { Keterampilan } \\
\text { menginvestigasi } \\
\text { (investigative } \\
\text { skills) }\end{array}$} & Keterampilan merancang investigasi \\
\hline & Keterampilan melaksanakan investigasi \\
\hline & Keterampilan melaporkan hasil investigasi \\
\hline
\end{tabular}

Berdasarkan hasil observasi pembelajaran IPA yang dilaksanakan pada tanggal 14 September 2016 di kelas VIII A dan wawancara terhadap guru IPA yang mengajar di kelas tersebut, menunjukkan bahwa guru lebih sering mengajar IPA dengan menggunakan model konvensional dengan metode ceramah, tanya jawab, dan penugasan. Guru menyampaikan materi IPA dan sejumlah fakta-fakta ilmiah sesuai dengan yang ada didalam buku teks pelajaran dan jarang sekali bahkan tidak pernah melatihkan KPS. Hasil wawancara menunjukkan bahwa guru menyatakan materi IPA yang terlalu banyak jika dibandingkan dengan waktu mengajar efektif. Hal tersebut menjadi alasan guru mengajar IPA dengan menggunakan model konvensional agar materi tersampaikan semua kepada peserta didik sebelum peserta didik menghadapi ujian tengah semester (UTS) dan ujian akhir semester (UAS). Model konvensional dipandang belum dapat mengembangkan KPS peserta didik. KPS yang tidak dilatihkan oleh guru menyebabkan peserta didik hanya sebagai pembelajar pasif di kelas, tidak memiliki keterampilan proses untuk menyelidiki alam, memecahkan masalah, dan membuat keputusan.

Alternatif yang dapat digunakan guru untuk meningkatkan penguasaan KPS salah satunya adalah model inquiry. Model inquiry merupakan model pembelajaran yang berfokus pada proses yang menuntut peserta didik melakukan penyelidikan 
secara otentik, menemukan dan menggunakan berbagai sumber informasi dan ide untuk meningkatkan pemahaman mereka tentang masalah atau topik (Reda, 2016). Pada saat pembelajaran, peserta didik dituntut untuk mengajukan pertanyaan dan menjawab pertanyaan dengan benar tetapi jawaban harus didukung hasil penyelidikan atau investigasi baik secara kelompok maupun individu. Hal tersebut diharapkan akan dapat mengembangkan penguasaan KPS dan motivasi belajar peserta didik. Model inquiry yang dapat diterapkan pada penelitian ini adalah model guided inquiry (inkuiri terbimbing) melalui lesson study. Lesson study merupakan suatu tindakan mengkaji pembelajaran secara bersama-sama oleh sekelompok guru secara kolaboratif dan berkesinambungan dalam rangka untuk meningkatkan kualitas proses pembelajaran (Syamsuri \& Ibrohim, 2008).

Model guided inquiry merupakan suatu pendekatan yang membantu peserta didik melalui proses inkuiri, mendorong keterlibatan, dan refleksi pada setiap tahap pembelajaran (Kuhlthau, Maniotes, \& Caspari, 2015). Model guided inquiry cocok digunakan pada kelas dengan peserta didik yang belum mempunyai pengalaman belajar dengan model inkuiri (Mulyasa, 2009). Pada model guided inquity, guru memiliki peranan yang cukup besar dalam memberikan bimbingan. Sebagain besar perencanaan pembelajaran dibuat oleh guru dan peserta didik tidak merumuskan masalah. Guru memfasilitasi peserta didik untuk belajar satu sama lain pada setiap tahap penyelidikan dengan memberikan kesempatan peserta didik untuk berkolaborasi dengan peserta didik lain. Guru memastikan bahwa aktivitas penyelidikan menghasilkan wawasan baru dan tidak memberikan dugaan yang salah, guru memantau kemajuan peserta didik secara teratur dan membantu peserta didik mengeksplorasi masalah yang kompleks, guru dapat juga berkolaborasi guru lain untuk menganalisis hasil penyelidikan dan kesimpulan peserta didik (Linn et al., 2014).

Penelitian tentang model guided inquiry untuk mengembangkan penguasaan KPS telah banyak dilaporkan pada sekolah dasar, menengah dan perguruan tinggi pada materi tertentu pada berbagai bidang studi atau mata pelajaran. Penelitian menggunakan model guided inquiry pada mata kuliah kimia obat untuk mahasiswa farmasi mampu menciptakan keterampilan proses utama seperti pemikiran kritis dan komunikasi yang penting bagi keberhasilan praktik apoteker (Brown, 2010).

Materi struktur jaringan tumbuhan, fotosintesis dan gerak pada tumbuhan adalah materi yang bersifat abstrak dan cukup sulit dipahami oleh peserta didik tanpa melalui penyelidikan.
Penyelidikan membuat peserta didik mengalami langsung dan melakukan rangkaian proses belajar sehingga diharapkan penguasaan KPS berkembang dan pembelajaran menjadi bermakna. Sintaks pembelajaran model guided inquiry meliputi 1) memulai penyelidikan, 2) mengumpulkan data, 3) menganalsis data, 4) membuat kesimpulan yang koheren untuk menjelaskan fenomena kompleks (Linn et al., 2014). Pendapat lain menyatakan bahwa sintak dari model guided inquiry. 1) mengajukan pertanyaan dan membuat prediksi; 2) menyelidiki solusi melalui eksperimen; 3) menciptakan pengetahuan baru dan model; 4) mendiskusikan penemuan dan pengalaman; 5) merefleksikan penemuan baru atau memulai pertanyaan baru (Mikroyannidis et al., 2013). Pembelajaran menggunakan model guided inquity memiliki sejumlah kelebihan diantaranya yaitu 1) memiliki menekankan pada aspek kognitif, afektif dan psikomotor secara seimbang, 2) mendorong peserta didik untuk berpikir ilmiah dan melakukan kerja ilmiah dalam setiap pemecahan masalah, 3) menumbuhkan sikap objektif, jujur dan terbuka. Adapun kekurangan dari model guided inquiry yaitu 1) perlu perencanaan yang teratur dan matang bagi guru yang tidak terbiasa dengan model inkuiri akan terasa menjadi beban yang memberatkan, 2) pelaksanaan model guided inquiry membutuhkan waktu yang cukup panjang untuk melakukan pembuktikan secara ilmiah melalui penyelidikan /investigasi, 3) proses jalannya inquiry akan terhambat jika peserta didik sudah terbiasa dengan cara belajar yang hanya menerima tanpa kritik dan pasif apa yang diberikan guru.

Berdasarkan latar belakang dan referensi yang dikemukakan diatas maka penelitian tentang implementasi model guided inquiry melalui lesson study untuk meningkatkan penguasaan keterampilan proses sains (KPS) pada peserta didika kelas VIIIA SMP Muhammadiyah 3 Purwokerto dianggap penting untuk dilakukan. Adapun tujuan penelitian ini adalah mengetahui keefektifan implementasi model guided inquiry pada pembelajaran IPA melalui lesson study untuk meningkatkan penguasaan KPS peserta didik kelas VIIIA SMP Muhammadiyah 3 Purwokerto.

\section{Metode}

Jenis penelitian ini adalah penelitian tindakan melalui lesson study. Penelitian ini dilaksanakan di SMP Muhammadiyah 3 Purwokerto pada semester gasal tahun ajaran 2016/2017 dengan subjek penelitian sebanyak 23 peserta didik di kelas VIII A. Penelitian ini dilaksanakan sebanyak 6 siklus pada 
materi struktur dan fungsi jaringan tumbuhan, fotosintesis dan gerak pada tumbuhan. Pada masingmasing siklus terdiri atas tiga tahap yaitu plan, do, dan see.

Lesson Study dilaksanakan oleh tim yang terdiri atas satu dosen Pendidikan Biologi Universitas Muhammadiyah Purwokerto dan dua guru IPA. Pada kegiatan plan, tim lesson study berdiskusi untuk menganalisis materi, menyusun RPP dengan model guided inquiry, mendiskusikan skenario pembelajaran model guided inquiry, menentukan media, menyusun lembar kegiatan peserta didik (LKPD/LKS) dan menentukan teknik dan instrumen penilaian. Pada kegiatan do, dilaksanakan praktek pembelajaran oleh guru model dan observasi pembelajaran oleh tim observer. Pada kegiatan see, dilaksanakan refleksi kegiatan pembelajaran bersama dengan tim lesson study sebagai bahan evaluasi dan pertimbangan dalam merencanakan kegiatan pembelajaran pada siklus selanjutnya. Secara keseluruhan, peneliti dan guru IPA yang tergabung dalam tim lesson study secara kolaboratif melaksanakan seluruh kegiatan lesson study mulai dari plan, do dan see sebagai bentuk perbaikan pembelajaran secara terus menerus (continouse improvement).

Teknik dan instrumen pengumpulan data yang digunakan dalam penelitian ini adalah wawancara terhadap guru IPA untuk mengumpulkan data awal tentang kondisi peserta didik dan pembelajaran IPA; observasi dengan menggunakan lembar observasi untuk mengetahui aktivitas belajar peserta didik terutama yang berkaitan dengan aktivitas KPS yang muncul pada saat pembelajaran. Observasi juga dilakukan terhadap guru model untuk mengetahui keterlaksanaan sintaks model guided inquiry sehingga memastikan bahwa tidak ada sintaks yang terlewatkan selama pembelajaran IPA berlangsung. Tes menggunakan instrumen tes tertulis non objektif sebanyak 25 item soal digunakan untuk menggali penguasaan KPS peserta didik (Gambar 1) dan indikator KPS yang diukur tersaji pada Tabel 2. Instrumen tes digunakan merupakan adaptasi dari instrumen tes KPS yang dikembangkan oleh Bambang Subali tahun 2009 yang disesuaikan dengan materi di SMP. Validitas instrumen tes diselidiki menggunakan teori respon item (Item Respons Theory/RRT) dengan batas INFT MNSQ 0,77 sampai dengan 1,30 sehingga dapat dinyatakan valid. Reliabilitas item tes berdasarkan error of measurement yaitu sebesar 0,96 dengan nilai reliabilitas Croanbach Alpha berdasarkan internal consistency untuk data politomus yaitu sebesar 0,70 .

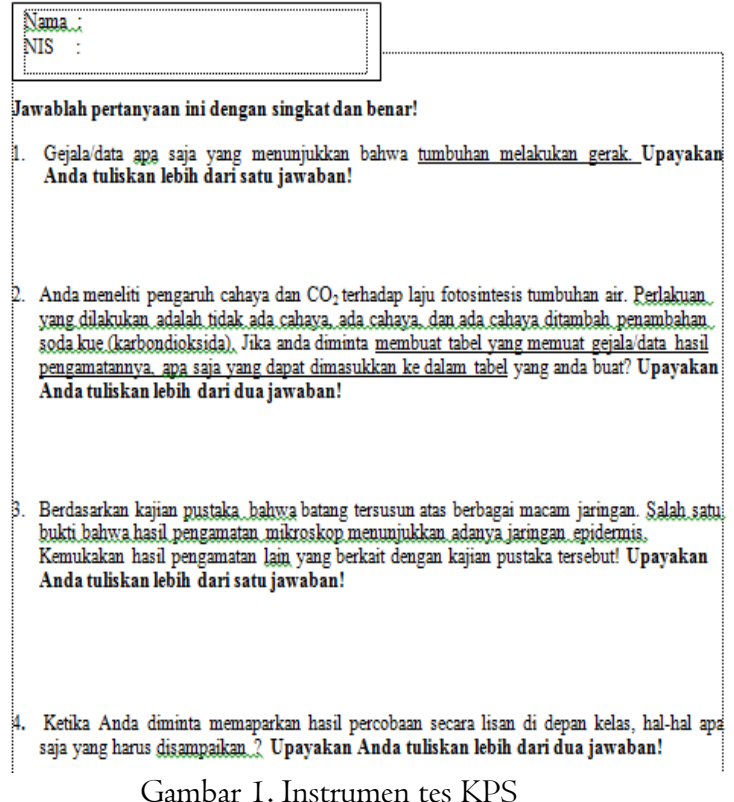

Teknik analisis data yang digunakan dalam penelitian ini adalah analisis secara deskriptif kualitatif dan kuantitatif. Analisis deskriptif kualitatif berupa data hasil refleksi pada setiap siklus. Analisis deskriptif kuantitatif dilakukan terhadap data hasil observasi pembelajaran dan data hasil tes KPS peserta didik menggunakan instrumen tes.

Tabel 2. Indikator Keterampilan Proses Sains

\begin{tabular}{|c|c|c|}
\hline No & Aspek KPS & Indikator \\
\hline 1. & $\begin{array}{l}\text { Keterampilan } \\
\text { melakukan } \\
\text { pengamatan }\end{array}$ & $\begin{array}{l}\text { Mengidentifikasi jenis data yang } \\
\text { dapat dihimpun dalam melakukan } \\
\text { pengamatan sesuai dengan alat indera } \\
\text { yang digunakan } \\
\text { Mencocokkan suatu objek dengan } \\
\text { beragam representasi visualnya } \\
\text { Mengidentifikasi situasi berpotensi } \\
\text { penuh resiko saat bekerja di } \\
\text { sekolah/laboratorium dalam } \\
\text { kehidupan sehari-hari }\end{array}$ \\
\hline 2. & $\begin{array}{l}\text { Keterampilan } \\
\text { melakukan } \\
\text { merekam } \\
\text { data/informasi }\end{array}$ & $\begin{array}{l}\text { Memberi label suatau bagan atau } \\
\text { diagram } \\
\text { Menghasilkan tema yang tepat } \\
\text { beserta informasi yang ada di } \\
\text { dalamnya }\end{array}$ \\
\hline 3. & $\begin{array}{l}\text { Keterampilan } \\
\text { melakukan } \\
\text { pengukuran }\end{array}$ & $\begin{array}{l}\text { Melakukan pengukuran dengan } \\
\text { menggunakan alat ukur yang } \\
\text { skalanya dibaca dengan posisi } \\
\text { horisontal }\end{array}$ \\
\hline 4. & $\begin{array}{l}\text { Keterampilan } \\
\text { melakukan } \\
\text { manipulasi } \\
\text { gerakan }\end{array}$ & $\begin{array}{l}\text { Mendemontrasikan kendali motor } \\
\text { kasar dengan berbagai cara } \\
\text { (menjalankan mesin/motor) }\end{array}$ \\
\hline 5. & $\begin{array}{l}\text { Keterampilan } \\
\text { mengimplement } \\
\text { asikan } \\
\text { prosedur/tekni } \\
\mathrm{k} / \text { penggunaan } \\
\text { peralatan }\end{array}$ & $\begin{array}{l}\text { Mengadopsi prosedur laboratorium } \\
\text { dengan memperkecil/ } \\
\text { meminimalkan resiko/ kesalahan } \\
\text { Menghasilkan alat ukur untuk } \\
\text { menghasilkan suatu volume tertentu } \\
\text { yang ditetapkan } \\
\text { Menyiapkan preparat untuk diamati }\end{array}$ \\
\hline
\end{tabular}




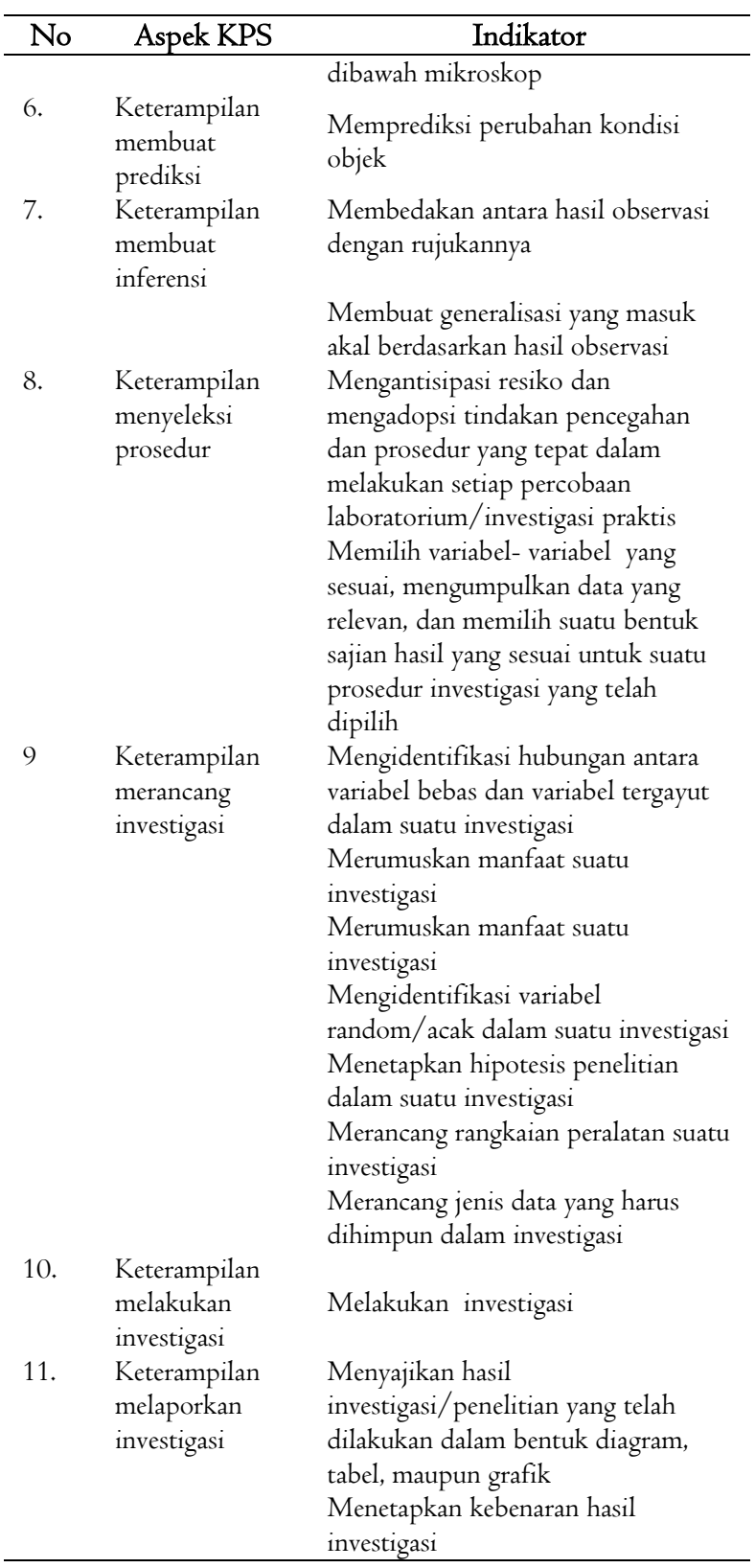

\section{Hasil dan pembahasan}

Hasil refleksi pembelajaran kegiatan lesson study pada tahap see yang disampaikan oleh anggota tim menunjukan indikasi perbaikan proses pembelajaran dari siklus 1 hingga siklus 6 (Tabel 3).

Hasil observasi KPS peserta didik menggunakan lembar observasi aktivitas KPS menunjukan kecenderungan adanya peningkatan persentase jumlah peserta didik yang melakukan aktivitas KPS yaitu pada siklus 1, siklus 2, siklus 3, siklus 5 dan siklus 6 sedangkan pada siklus 4 terjadi penurunan (Gambar 2). Persentase peserta didik yang melakukan KPS secara berturut-turut adalah sebesar 43\% (kurang), 56\% (cukup), 61\% (cukup), $52 \%$ (cukup), 65\% (cukup), dan 69\% (cukup).

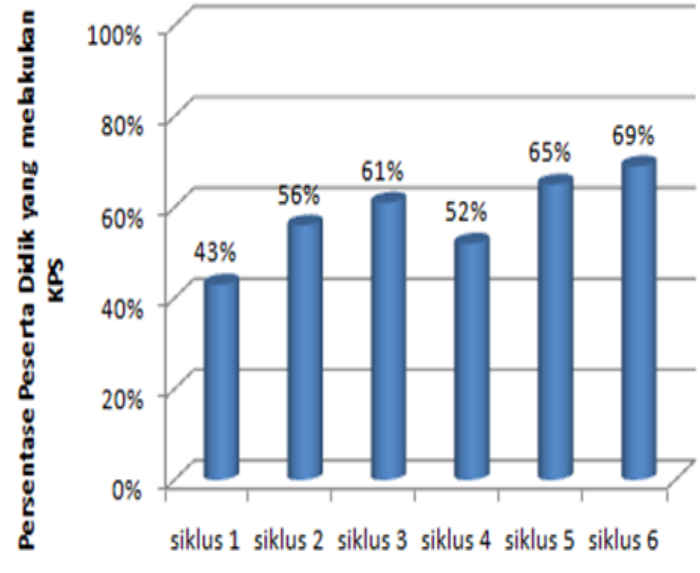

Gambar 2. Persentase peserta didik yang melakukan aktivitas KPS

Hasil observasi menunjukkan bahwa tidak semua aspek KPS yang diamati muncul pada setiap siklusnya. Aspek basic skills dan process skills hampir seluruhnya muncul pada setiap siklus, sedangkan pada aspek investigation skills hampir tidak ada muncul pada setiap siklusnya kecuali aspek merumuskan hipotesis yang muncul pada siklus 4 . Hasil tes untuk mengukur penguasaan KPS peserta didik yang dilaksanakan setelah pembelajaran siklus 6 menunjukkan bahwa rata-rata nilai penguasaan KPS peserta didik adalah sebesar 74,5 dengan standar deviasi 7,9; nilai minimum 57,1 dan nilai maksimum 83,9 (Gambar 3). Nilai penguasaan KPS peserta didik sebesar 74,5 dengan nilai standar deviasi yang cukup rendah yaitu 7,9 pada skala 100. Hal ini menunjukkan bahwa peserta didik memiliki penguasaan KPS termasuk dalam kategori baik dengan kemampuan yang relative sama atau homogen pada masing-masing peserta didik.

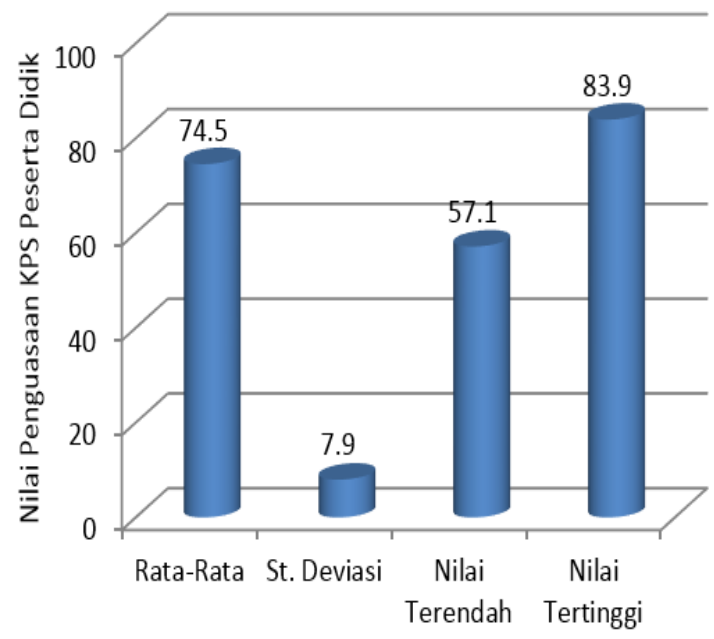

Gambar 3. Hasil tes penguasaan KPS peserta didik 
Tabel 3. Refleksi kegiatan lesson study pada siklus 1 hingga siklus 6

\begin{tabular}{|c|c|c|c|c|c|}
\hline $\begin{array}{c}\text { Siklus } 1 \\
\text { (RPP 1: Jaringan pada } \\
\text { tumbuhan) } \\
\end{array}$ & $\begin{array}{c}\text { Siklus } 2 \\
\text { (RPP 2: Organ } \\
\text { Tumbuhan) } \\
\end{array}$ & $\begin{array}{c}\text { Siklus } 3 \\
\text { (RPP 3: Fotosintesis } \\
\text { menghasilkan oksigen) } \\
\end{array}$ & $\begin{array}{c}\text { Siklus } 4 \\
\text { (RPP 3: Fotosintesis } \\
\text { menghasilkan amilum) }\end{array}$ & $\begin{array}{c}\text { Siklus } 5 \\
\text { (RPP } 5 \text { : Gerak Nasti) }\end{array}$ & $\begin{array}{c}\text { Siklus } 6 \\
\text { (RPP 6 : Gerak Tropisme) }\end{array}$ \\
\hline $\begin{array}{l}\text { Proses pembelajaran melebihi } \\
\text { waktu yang disediakan }\end{array}$ & $\begin{array}{l}\text { Proses pembelajaran } \\
\text { berlangsung sesuai dengan } \\
\text { waktu yang disediakan }\end{array}$ & $\begin{array}{l}\text { Proses pembelajaran sesuai dengan } \\
\text { waktu yang disediakan }\end{array}$ & $\begin{array}{c}\text { Proses pembelajaran sesuai } \\
\text { dengan waktu yang } \\
\text { disediakan }\end{array}$ & $\begin{array}{c}\text { Proses pembelajaran melebihi waktu } \\
\text { yang disediakan }\end{array}$ & $\begin{array}{l}\text { Proses pembelajaran sesuai } \\
\text { dengan waktu yang disediakan }\end{array}$ \\
\hline $\begin{array}{c}\text { Semua kelompok sudah } \\
\text { membawa bahan/alat yang } \\
\text { ditugaskan guru }\end{array}$ & $\begin{array}{l}\text { Semua kelompok sudah } \\
\text { membawa bahan/alat yang } \\
\text { ditugaskan guru }\end{array}$ & $\begin{array}{l}\text { Alat dan bahan sudah disediakan } \\
\text { oleh guru }\end{array}$ & $\begin{array}{c}\text { Semua kelompok sudah } \\
\text { membawa bahan (daun) yang } \\
\text { ditugaskan guru }\end{array}$ & $\begin{array}{l}\text { Alat (stopwatch) sudah disediakan } \\
\text { oleh guru, sedangkan putri malu } \\
\text { diamati dilingkungan sekitar sekolah }\end{array}$ & $\begin{array}{l}\text { Semua kelompok sudah } \\
\text { membawa alat (pot) dan bahan } \\
\text { (biji kacang hijau) yang } \\
\text { ditugaskan guru }\end{array}$ \\
\hline $\begin{array}{l}\text { Pada masing-masing kelompok } \\
\text { hanya satu atau tiga orang dari } \\
\text { lima anggota ( } 20 \%-60 \%) \text { yang } \\
\text { melaksanakan kegiatan sesuai } \\
\text { LKS. }\end{array}$ & $\begin{array}{l}\text { Pada masing-masing } \\
\text { kelompok } 60 \% \text { anggota } \\
\text { kelompok melaksanakan } \\
\text { kegiatan sesuai LKS. }\end{array}$ & $\begin{array}{l}\text { Tampak sudah ada kelompok ( } 3 \\
\text { kelompok dari } 5 \text { kelompok) yang } \\
\text { melakukan pembagian tugas pada } \\
\text { masing-masing anggota kelompok } \\
\text { yang memungkinkan anggota } \\
\text { kelompok kerja semua. }\end{array}$ & $\begin{array}{c}\text { Seluruh kelompok telah } \\
\text { melakukan pembagian tugas } \\
\text { pada masing-masing anggota } \\
\text { kelompok yang } \\
\text { memungkinkan anggota } \\
\text { kelompok kerja semua. }\end{array}$ & $\begin{array}{l}\text { Pada masing-masing kelompok } 60 \% \\
\text { anggota kelompok melaksanakan } \\
\text { kegiatan sesuai LKS sedang yang lain } \\
\text { bermain-main di lingkungan sekitar }\end{array}$ & $\begin{array}{c}\text { Seluruh kelompok telah } \\
\text { melakukan pembagian tugas } \\
\text { pada masing-masing anggota } \\
\text { kelompok yang } \\
\text { memungkinkan anggota } \\
\text { kelompok kerja semua. }\end{array}$ \\
\hline $\begin{array}{c}\text { Sekitar } 50 \% \text { peserta tidak serius } \\
\text { dalam penyelidikan dan bermain } \\
\text { sendiri }\end{array}$ & $\begin{array}{c}\text { Lebih dari } 40 \% \text { peserta } \\
\text { didik aktif dalam } \\
\text { mengerjakan kegiatan di } \\
\text { LKS } \\
\end{array}$ & $\begin{array}{c}\text { Sekitar } 60 \% \text { peserta didik aktif } \\
\text { dalam mengerjakan kegiatan di LKS } \\
\text { dengan baik }\end{array}$ & $\begin{array}{l}\text { Sekitar } 50 \% \text { peserta didik } \\
\text { aktif dalam mengerjakan } \\
\text { kegiatan di LKS dengan baik }\end{array}$ & $\begin{array}{c}\text { Sekitar } 60 \% \text { peserta didik aktif } \\
\text { dalam mengerjakan kegiatan di LKS } \\
\text { dengan baik }\end{array}$ & $\begin{array}{l}\text { Sekitar } 60 \% \text { peserta didik } \\
\text { aktif dalam mengerjakan } \\
\text { kegiatan di LKS dengan baik }\end{array}$ \\
\hline $\begin{array}{l}\text { Hampir seluruh kelompok } \\
\text { belum mampu menggunakan } \\
\text { mikroskop dengan baik untuk } \\
\text { mengamati objek sehingga peran } \\
\text { guru masih sangat besar }\end{array}$ & $\begin{array}{l}\text { Masing-masing angota } \\
\text { kelompok (100\%) telah } \\
\text { melakukan pengamatan } \\
\text { terhadap objek (tumbuhan) } \\
\text { yang dibawa dengan baik } \\
\text { namun beberapa peserta } \\
\text { didik yang kurang terampil } \\
\text { dalam analisa data } \\
\end{array}$ & $\begin{array}{c}\text { Hujan turun sehingga cahaya } \\
\text { matahari digantikan dengan sinar } \\
\text { senter. Terdapat kelompok dengan } \\
\text { hasil penyelidikan yang tidak sesuai } \\
\text { dengan yang diharapkan } \\
\text { mengakibatkan peserta didik } \\
\text { mengalami kesulitan dalam analisis } \\
\text { data dan pengambilan kesimpulan } \\
\end{array}$ & $\begin{array}{l}\text { Peserta didik sudah mampu } \\
\text { menggunakan alat dengan } \\
\text { baik pada percobaan Sach, } \\
\text { kesulitan dalam menyusun } \\
\text { hipotesis dan kesimpulan }\end{array}$ & $\begin{array}{l}\text { Beberapa kelompok kurang teliti } \\
\text { dalam melakukan pengamatan } \\
\text { sehingga harus diualng beberapa kali, } \\
\text { beberapa siswa belum bisa } \\
\text { menggunakan stopwatch dengan } \\
\text { benar, peserta didikkurang cekatan } \\
\text { saat diminta kembali ke kelas }\end{array}$ & $\begin{array}{c}\text { Seluruh kelompok telah } \\
\text { mampu menyusun preangkat } \\
\text { percobaan dengan baik sesuai } \\
\text { LKS, beberapa kelompok } \\
\text { kesulitan menyusun hipotesis } \\
\text { dan analisis data }\end{array}$ \\
\hline $\begin{array}{l}\text { 60\% kelompok tidak } \\
\text { menyelesaikan LKS dengan } \\
\text { tuntas sehingga harus } \\
\text { diselesaikan dirumah } \\
\end{array}$ & $\begin{array}{l}100 \% \text { kelompok telah } \\
\text { menyelesaikan LKS dengan } \\
\text { tuntas }\end{array}$ & $\begin{array}{l}100 \% \text { kelompok telah } \\
\text { menyelesaikan LKS dengan tuntas }\end{array}$ & $\begin{array}{c}100 \% \text { kelompok telah } \\
\text { menyelesaikan LKS dengan } \\
\text { tuntas }\end{array}$ & $\begin{array}{l}\text { Hanya } 80 \% \text { kelompok telah } \\
\text { menyelesaikan LKS dengan tuntas }\end{array}$ & $\begin{array}{c}100 \% \text { kelompok telah } \\
\text { menyelesaikan LKS dengan } \\
\text { tuntas }\end{array}$ \\
\hline $\begin{array}{l}\text { Kegiatan peserta didik hanya } \\
\text { sampai pada menyelasaikan } \\
\text { prosedur LKS dan menarik } \\
\text { kesimpulan, belum sampai pada } \\
\text { presentasi di depan kelas }\end{array}$ & $\begin{array}{l}\text { Dua kelompok telah } \\
\text { menyampaikan hasil } \\
\text { penyelidikan di depan kelas } \\
\text { dengan cara ditunjuk guru }\end{array}$ & $\begin{array}{l}\text { Beberepa kelompok telah berani } \\
\text { untuk tampil mempresentasikan } \\
\text { hasil penyelidikan dengan suka rela. }\end{array}$ & $\begin{array}{c}\text { Kelompok berebut untuk } \\
\text { mempresentasikan hasil } \\
\text { penyelidikan dengan suka rela } \\
\text { dan menjawab pertanyaan } \\
\text { dari guru }\end{array}$ & $\begin{array}{c}\text { Kelompok yang sudah selesai } \\
\text { mempresentasikan hasil penyelidikan } \\
\text { dengan suka rela dan menjawab } \\
\text { pertanyaan dari guru }\end{array}$ & $\begin{array}{c}\text { Perwakilan kelompok } \\
\text { mempresentasikan hasil } \\
\text { penyelidikan dengan suka rela } \\
\text { dan menjawab pertanyaan dari } \\
\text { guru }\end{array}$ \\
\hline
\end{tabular}




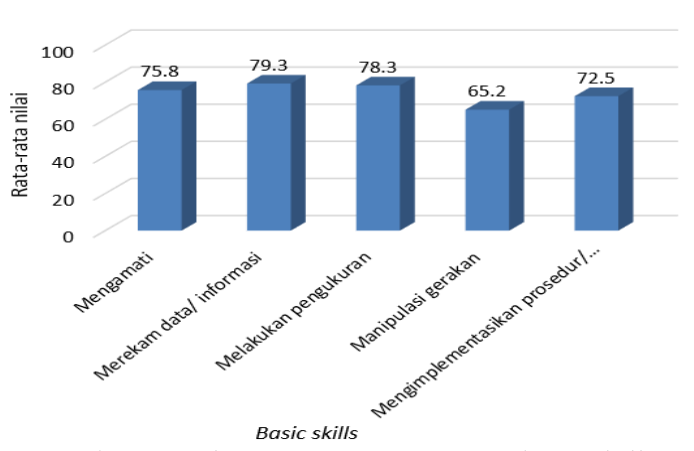

Gambar 4. Nilai rata-rata penguasaan basic skills peserta didik

Hasil tes penguasaan KPS peserta didik pada aspek penguasaan keterampilan dasar (basic skills) diperoleh rata-rata nilai yaitu 75,8 (mengamati), 79,3 (merekam data/informasi), 78,3 (melakukan pengukuran), 65,2 (manipulasi gerakan) dan 72, 5 (implementasi prosedur; Gambar 4). Hasil penilaian keterampilan proses (process skills) diperoleh ratarata nilai yaitu 60,9 (membuat prediksi), 70,3 (membuat inferensi) dan 58,2 (menyeleksi prosedur), sedangkan keterampilan penyelidikan (investigative skills) diperoleh rata-rata nilai yaitu 52,1 (merancang investigasi), 76,1 (melaksanakan investigasi), dan 77,2 (melaporkan investigasi).

Hasil penelitian menunjukkan bahwa model guided inquity melalui lesson study mampu mengembangkan penguasaan KPS peserta didik pada mata pelajaran IPA materi struktur jaringan tumbuhan, fotosintesis dan gerak tumbuhan (Gambar 2 dan Gambar 3). Hasil penelitian yang serupa juga pernah dilaporkan bahwa penerapan model inkuiri dengan lesson study dalam pembelajaran biologi pada peserta didik kelas VII SMPN I Singosari dapat meningkatkan penguasaan KPS dan sikap ilmiah peserta didik (Budur, 2013). Model guided inquiry juga mampu mengingkatkan penguasaan KPS dan penguasaan konsep lebih baik peserta didik kelas 6 sekolah dasar pada kelas eksperimen jika dibandingkan dengan kelas kontrol (Koksal \& Berberoglu, 2014). Hasil penelitian yang serupa juga dilaporkan bahwa terjadi peningkatan penguasaan KPS melalui PTK pada peserta didik kelas VII SMP menggunakan model guided inquiry (Yuniastuti, 2013).

Hasil penelitian menunjukkan sebagian besar basic skills dikuasai dengan baik oleh peserta didik kecuali keterampilan melakukan manipulasi gerakan (cukup). Keterampilan manipulasi gerakan dikuasai dalam kategori cukup karena peserta didik hanya sekedar mengikuti petunjuk LKS yang dibuat oleh guru tanpa melakukan inovasi, padahal pemikiran orisinalitas dan penemuan yang sangat penting kaitannya dengan memanipulasi keterampilan sebagai bekal dasar penguasaan keterampilan yang lebih tinggi yaitu ketrampilan terintegrasi/investigative skills (Akinbobola \& Afolabi, 2010). Pengembangan LKS yang terstruktur yang disusun oleh guru dalam model guided inquiry dapat menjadi hambatan pengembangan keterampilan manipulasi sebagai bentuk kreativitas peserta didik. LKS yang terstruktur tidak memberikan ruang kepada peserta didik berpikir untuk mencari sendiri apa yang harus diamati atau diukur dan berpikir tentang alternative cara pengukuran (Subali, 2011). Penguasaan process skills meliputi kemampuan membuat prediksi dikuasai dalam kategori cukup, membuat inferensi dikuasai dalam kategori baik dan menyeleksi prosedur dikuasai dengan kategori rendah. Salah satu sintaks model guided inquiry adalah membuat kesimpulan yang koheren untuk menjelaskan suatu fenomena sehingga selama 6 siklus peserta didik terbiasa membuat kesimpulan walaupun dibawah bimbingan dari guru.

Terdapat kecenderungan kemampuan penguasaan process skills dan investigative skills peserta didik lebih rendah jika dibandingkan dengan penguasaan basic skills (Gambar 5). Hal ini karena process skills dan investigative skills merupakan KPS lanjutan yang memiliki tingkat kesulitan yang lebih tinggi dari basic skills (Handayani, Kirana, Tjandra, \& Kardi, 2012). Keterampilan proses sains dasar hingga lanjutan idealnya sudah harus diajarkan sejak dini sehingga peserta didik sudah terbiasa belajar KPS. Secara umum sintaks/tahap-tahap pada model guided inquiry sangat mendukung bagi dilaksanakannya kegiatan KPS. Pembelajaran guided inquiry memberi peserta didik pengalaman belajar yang didukung dengan contoh-contoh mendalam dari lingkungan sekitar sehingga peserta didik memiliki kesempatan untuk terlibat dalam kegiatan konkrit yang memfasilitasi pengembangan KPS mereka. Peserta didik memiliki kesempatan untuk bertanya, merumuskan solusi, melakukan observasi, dan menarik kesimpulan (Nworgu \& Otum, 2013).

Lingkungan sekitar dinilai sebagai sumber belajar yang efektif jika dibandingkan dengan buku (Nur, 2012). Peserta didik cenderung lebih berhasil dalam tugas pembelajaran ketika beralih ke lingkungan sekitar mereka. Pembelajaran dengan melibatkan lingkungan sekitar dapat memunculkan minat dan motivasi peserta didik untuk terlibat dalam tugas-tugas yang relevan yang berdampak dalam pengembangan penguasaan keterampilan proses sains. Peserta didik dapat mengintegrasikan beragam langkah penyelidikan melalui aktivitas KPS sebagai strategi visual dan alat mediasi untuk mendapatkan penalaran ilmiah (Mikroyannidis et al., 2013). 


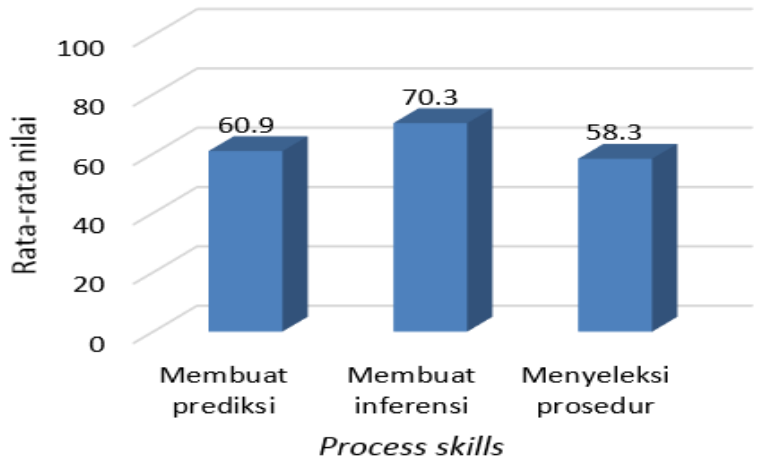

(A)

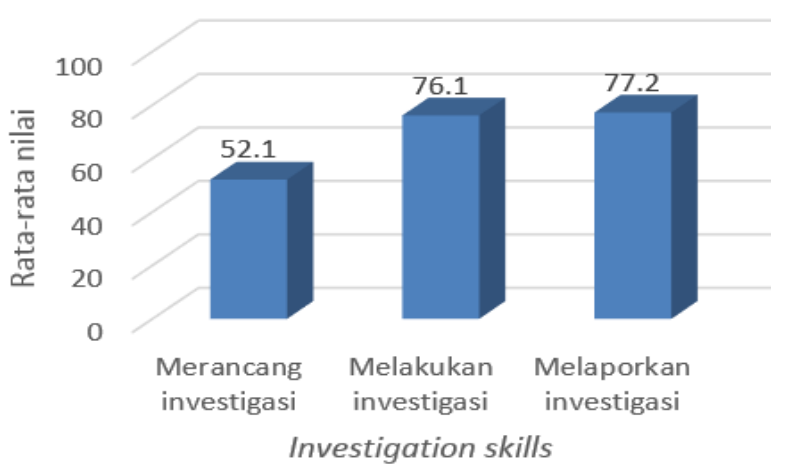

(B)

Gambar 5. Nilai rata-rata penguasaan process skills (A) dan investigative skills peserta didik (B)

Model guided inquiry diawali dengan orientasi masalah. Orientasi masalah akan menimbulkan rasa ingin tahu, pemikiran yang bermakna dengan caracara yang luar biasa (powerful ways) yang mendorong peserta didik untuk melakukan penyelidikan/investigasi (Tan, Chye, \& Teo, 2009). Masalah yang digali dalam pembelajaran dengan model guided inquiry adalah masalah yang tidak hanya menuntut jawaban benar secara teori tetapi memerlukan penyelidikan, investigasi, eksperimen dan kerja ilmiah lebih lanjut untuk mengkonfirmasi kebenaran jawaban yang diberikan. Penyelidikan/investigasi dan eksperimen dalam belajar IPA selalu melibatkan sejumlah keterampilan proses sains (KPS). Pembelajaran yang demikian akan melatihkan KPS kepada peserta didik sehingga mampu mengembangkan penguasaan KPS peserta didik. Menurut Csikzentmihalyi (Barrett, 2010), menyatakan bahwa masalah yang didesain dengan cukup menantang akan memberikan stimulasi kepada peserta didik untuk mengembangkan tingkat pengetahuan dan keterampilannya dan menggunakan pengalamannya secara optimal untuk mencari solusi masalah.

Pada penelitian ini sebanyak 4 siklus pembelajaran dilaksanakan di laboratorium. Kegiatan belajar di laboratorium membuat peserta didik jauh lebih berfokus pada penggunaan peralatan dan bahan untuk membangun pengetahuan, termasuk menganalisis dan memvisualisasikan data, mengkomunikasikan, mengembangkan keterampilan teknis dan praktis, dan pemodelan (Wieman \& Holmes, 2015). Hal tersebut memungkinkan peserta didik mengembangkan keterampilan proses jika dibandingkan dengan pembelajaran konvensional.

Implementasi pembelajaran model guided inquiry yang dilaksanakan melalui lesson study tidak hanya memberikan dampak pada perbaikan kualitas pembelajaran khususnya peningkatan penguasaan KPS peserta didik tetapi juga sebagai model pelatihan pengembangan kompetensi keprofesionalan guru. Kegiatan plan LS yang dilaksanakan oleh guru IPA dan dosen sangat membantu guru dalam meningkatkan kemampuannya menyusun perangkat pembelajaran yang meliputi menentukan materi, menyusun RPP, menyusun LKS, menyusun instrument evaluasi dan penilaian hasil belajar peserta didik. Pada tahap do, meberikan pengalaman yang berharga bagi guru dalam pembelajaran berbasis inquiry/laboratorium yang sebelumnya memang jarang sekali dilakukan oleh guru. Hal tersebut diharapkan akan terus dapat dikembangkan oleh guru. Pada tahap see, refleksi dan masukkan yang diberikan oleh observer dan dosen akan sangat bermanfaat dalam perbaikan perangkat pembelajaran dan proses pembelajaran sehingga selanjutnya selanjutnya guru diharapkan akan dapat meningkatkan kualitas pembelajaran secara keseluruhan dan prestasi peserta didik dapat ditingkatkan. Hal yang lebih penting lagi bahwa LS menjadi suatu model terhadap peningkatan budaya refleksi diri dan budaya kerjasama yang semakin terkikis di era modern seperti sekarang ini. Budaya refleksi diri yaitu selalu merefleksi diri terhadap kondisi-kondisi yang terjadi. Diharapkan guru selalu berusaha mencari sebab kegagalan diri dan melakukan perbaikan agar kegagalan yang sama tidak terulang dikemudian hari. Budaya kerjasama dipandang sebagai kemampuan seseorang membantu rekannya untuk mencapai kesuksesan bersama (Prihantoro, 2011).

\section{Simpulan}

Berdasarkan hasil penelitian dan pembahasan maka dapat disimpulkan bahwa implementasi model pembelajaran guided inquiry melalui lesson study dapat mengembangkan penguasaan keterampilan proses sains (KPS) peserta didik kelas VIIIA SMP Muhammadiyah 3 Purwokerto. 


\section{Ucapan terima kasih}

Terimakasih penulis sampaikan kepada SMP Muhammadiyah 3 Purwokerto yang telah bersedia bekerjasama dalam penelitian ini. Terimakasih juga penulis sampaikan kepada FKIP UMP yang telah memberikan dana bagi terselenggaranya penelitian ini.

\section{Referensi}

Akinbobola, A. O., \& Afolabi, F. (2010). Analysis of science process skills in west african senior secondary school certificate physics practical examinations in nigeria. American-Eurasian journal of Scientific research, 5(4), 234-240. Diambil dari https://idosi.org/aejsr/ 5(4)10/3.pdf

Badan Standar Nasional Pendidikan. Standar isi untuk satuan pendidikan dasar dan menengah (2006). Indonesia: Kementerian Pendidikan dan Kebudayaan RI.

Barrett, T. (2010). The problem-based learning process as finding and being in flow. Innovations in Education and Teaching International, 47(2), 165-174. https://doi.org/10.1080/14703291 003718901

Brown, P. J. P. (2010). Process-oriented guided-inquiry learning in an introductory anatomy and physiology course with a diverse student population. Advances in Physiology Education, 34(3), 150-155. https://doi.org/10.1152/ advan.00055.2010

Bryce, T.G.K., McCall, J., MacGregor, J., Robertson, I.J., \& Weston, R. A. . (1990). Techniques for assesing process skill in practice science. Oxford: Heinemann Educational Books.

Budur, E. L. (2013). Integrasi pendidikan karakter melalui inkuiri dengan lesson study dalam pembelajaran biologi untuk meningkatkan sikap ilmiah dan hasil belajar kognitif siswa kelas VII SMPN I Singosari. Jurnal Pendidikan Sains, 1(2), 171177. Diambil dari http://journal.um.ac.id/ index.php/jps/article/view/4160/817

Handayani, S. A., Kirana, Tjandra, \& Kardi, S. (2012). Pengembangan perangkat pembelajaran IPA berorientasi metode penemuan terbimbing ( guided discovery) untuk meningkatkan keterampilan proses sains. Jurnal Penelitian Pendidikan Sains, 1(2), 108-115. Diambil dari https://journal.unesa.ac.id/index.php/jpps/arti cle/view/400/250

Harlen, W. (2001). The Assessment of Scientific Literacy in the OECD/PISA Project. Studies in Science Education, 36(1), 79-103. https://doi.org/ 10.1080/03057260108560168
Kemendikbud. Peraturan Menteri Pendidikan dan Kebudayaan Republik Indonesia Nomor 22 Tahun 2016 Tentang Standar Proses Pendidikan Dasar dan Menengah (2016). Indonesia: Kementerian Pendidikan dan Kebudayaan RI.

Koksal, E. A., \& Berberoglu, G. (2014). The effect of guided-inquiry instruction on 6th grade turkish students' achievement, science process skills, and attitudes toward science. International Journal of Science Education, 36(1), 66-78. https://doi.org/10.1080/09500693.2012.721 942

Kuhlthau, C. C., Maniotes, L. K., \& Caspari, A. K. (2015). Guided inquiry: Learning in the 21st century (2, revised ed.). California: ABC-CLIO, 2015. Google Books

Linn, M. C., Gerard, L., Ryoo, K., McElhaney, K., Liu, O. L., \& Rafferty, A. N. (2014). Computer-guided inquiry to improve science learning. Science, 344(6180), 155-156. https://doi.org/ $10.1126 /$ science. 1245980

Mikroyannidis, A., Okada, A., Scott, P., Rusman, E., Specht, M., Stefanov, K., ... Chaimala, F. (2013). weSPOT: A personal and social approach to inquiry-based learning. Journal of Universal Computer Science, 19(14), 20932111. Diambil dari http://jucs.org/ jucs_19_14/wespot_a_personal_and/jucs_19_ 14_2093_2111_mikroyannidis.pdf

Mulyasa, E. (2009). Menjadi guru profesional menciptakan pembelajaran kreatif dan menyenangkan. Bandung: Remaja Rosdakarya.

Nur, F. M. (2012). Pemanfaatan sumber belajar dalam pembelajaran sains kelas V SD pada pokok bahasan makhluk hidup dan proses kehidupan. Jurnal Penelitidan Pendidikan, 13(1), 67-78. Diambil dari http://jurnal.upi.edu/file/9Paizah-edit_67-79.pdf

Nworgu, L. N., \& Otum, V. V. (2013). Effect of guided inquiry with analogy instructional strategy on students acquisition of science process skills. Journal of Education and Practice, 4(27), 3540. Diambil dari https://www.iiste.org/ Journals/index.php/JEP/article/view/9880/1 0101

Prihantoro, R. (2011). Pengembangan profesionalisme guru melalui model lesson study. Jurnal Pendidikan dan Kebudayaan, 17(1), 100-108. https://doi.org/10.24832/jpnk.v17i1.10

Reda, S. (2016). Collaborative inquiry in ontario's kindergarten program. The International Journal of Holistic Early Learning and Development, 3(1), 72-77. Diambil dari https://ijheld. lakeheadu.ca/article/view/1502/834

Rezba, R. J., Sprague, C. R., Matkins, J. J., Fiel, R. L., \& Mcdonnough, J. T. (2007). Learning and 
Assessing Science Process Skills. (G. Botsford \& T. Bower, Ed.) (Fifth). United States of America: Kendall Hunt Publishing Company.

Subali, B. (2011). Pengukuran kreativitas keterampilan proses sains dalam konteks assessment for learning. Cakrawala Pendidikan, 30(1), 130144. https://doi.org/10.21831/cp.v1i1.4196

Syamsuri, I., \& Ibrohim. (2008). Lesson study (studi pembelajaran). Malang: FMIPA Universitas Negeri Malang.

Tan, O.-S., Chye, S., \& Teo, C. (2009). Problem-based learning and creativity: A review of the literature. In O.-S. Tan (Ed.), Problem-based learning and creativity. Singapore: Cengage Learning. Google Books

Wieman, C., \& Holmes, N. G. (2015). Measuring the impact of an instructional laboratory on the learning of introductory physics. American Journal of Physics, 83(11), 972-978. https://doi.org/10.1119/1.4931717

Yuniastuti, E. (2013). Peningkatan keterampilan proses, motivasi, dan hasil belajar biologi dengan strategi pembelajaran inkuiri terbimbing pada siswa kelas VII SMP Kartika V-1 Balikpapan. Jurnal Penelitian Pendidikan, 13(1), 80-88. Diambil dari http://ejournal.upi.edu/ index.php/JER/article/view/3509/2489 